ZOOLOGIA 31 (3): 215-222, June, 2014

http://dx.doi.org/10.1590/S1984-46702014000300002

\title{
Population biology of Aegla platensis (Decapoda: Anomura: Aeglidae) in a tributary of the Uruguay River, state of Rio Grande do Sul, Brazil
}

\author{
Marcelo M. Dalosto', Alexandre V. Palaoro', Davi de Oliveira', \\ Évelin Samuelsson ${ }^{2} \&$ Sandro Santos ${ }^{1,3}$
}

\begin{abstract}
${ }^{1}$ Núcleo de Estudos em Biodiversidade Aquática, Programa de Pós-Graduação em Biodiversidade Animal, Centro de Ciências Naturais e Exatas, Universidade Federal de Santa Maria. Avenida Roraima 1000, 97105-900 Santa Maria, RS, Brazil. 2 Programa de Pós-Graduação em Ecologia, Departamento de Ciências Biológicas, Universidade Regional Integrada do Alto Uruguai e das Missões. Avenida Sete de Setembro 1621, 99700-000 Erechim, RS, Brazil.

${ }^{3}$ Corresponding author. E-mail: sandro.santos30@gmail.com
\end{abstract}

\begin{abstract}
Aeglids are freshwater anomurans that are endemic from southern South America. While their population biology at the species-level is relatively well understood, intraspecific variation within populations has been poorly investigated. Our goal was to investigate the population biology of Aegla platensis Schmitt, 1942 from the Uruguay River Basin, and compare our data with data from other populations. We estimated biometric data, sex ratio, population density and size-class frequencies, and frequencies of ovigerous females and juveniles, from the austral spring of 2007 until autumn 2008. Sexual dimorphism was present in adults, with males being larger than females. Furthermore, males and females were significantly larger than previously recorded for the species. The overall sex ratio was 1.33:1 (male:female), and population density ranged from 1.8 (spring) to 3.83 ind. $\mathrm{m}^{-2}$ (winter). Data from this population differ from published information about $A$. platensis in almost all parameters quantified except for the reproductive period, which happens in the coldest months, and a population structure with two distinct cohorts. Difference among studies, however, may be in part due to methodological differences and should be further investigated in order to determine their cause. In addition to different methodologies, they may result from ecological plasticity or from the fact that the different populations actually correspond to more than one species.
\end{abstract}

KEY WORDS. Aeglids; ecological plasticity; intraspecific variation; population density; sampling methods; sex ratio.

Aeglids are freshwater anomuran crustaceans with benthonic habits, whose distribution is restricted to temperate and subtropical regions of South America (Buckup \& Bond-Buckup 1999, Bond-Buckup 2003). These crustaceans occur in river basins in Southern Brazil, Uruguay, Argentina, Southern Bolivia, Paraguay and South-central Chile, with 70 species currently described (SANTos et al. 2013). Albeit ubiquitous in well-oxygenated running waters in these regions (DALOSTO \& SANTOS 2011), several species have a very restricted distribution (BonDBuckup et al. 2008).

Understanding the basic traits of an organism's biology is important because it provides basic information for a wide array of studies. In the case of aeglids, these range from conservation efforts (Pérez-Losada et al. 2009) to the use of model species in laboratory studies (Palaoro et al. 2013, Siqueira et al. 2013). There is a considerable amount of studies on the basic biology of aeglids, such as population structure and dynamics (e.g., BuENO \& Bond-Buckup 2000, Fransozo et al. 2003, Cohen et al. 2011, Grabowski et al. 2013). However, previous studies on aeglids focused solely on the population dynamics of one species in a single location (e.g., Bueno \& Bond-Buckup 2000, Fransozo et al. 2003, Cohen et al. 2011, GrabowsKi et al. 2013). Ecological plasticity and variation in population biology parameters have been documented for other freshwater organisms, such as crayfish (Honan \& Mitchell 1995, Austin 1998, Beatty et al. 2004, 2011), which share ecological similarities to aeglids (BOND-BuckuP \& Buckup 1994, Nyström 2002, Ayres-Peres et al. 2011, Burress et al. 2013, Cogo \& Santos 2013).

Unlike other aeglids, Aegla platensis Schmitt, 1942 has broad distribution and relatively large populations. This species is recorded for Paraguay, Uruguay, Argentina and Brazil, where it occurs in the states of Rio Grande do Sul and Santa Catarina (Bond-Buckup 2003). The population dynamics and growth of $A$. platensis have been studied for a population in the Guaíba Basin in the state of Rio Grande do Sul (Bueno \& Bond-Buckup 2000 and Bueno et al. 2000, respectively). More recently, Oliveira \& SANTOS (2011) investigated the morphological sexual maturity of another population that inhabits the Uruguay River Basin, obtaining markedly different results from those reported by Bueno \& BOND-Buckup (2000) and Bueno et al. (2000).

2014 Sociedade Brasileira de Zoologia | www.sbzoologia.org.br | www.scielo.br/zool All content of the journal, except where identified, is licensed under a Creative Commons attribution-type BY-NC. 
Our goal was to investigate several characteristics of the population biology of $A$. platensis, such as sex ratio, population structure, reproductive/recruitment seasons and population density. Also, we compare our results with data already available for this species, and with information available for other aeglids. Lastly, we discuss the variations in the population biology of this group of crustaceans and whether or not it is productive to compare among data obtained using different methods.

\section{MATERIAL AND METHODS}

The Lajeado Bonito stream $\left(27^{\circ} 25^{\prime} 27^{\prime \prime} \mathrm{S} ; 53^{\circ} 24^{\prime} 39^{\prime \prime} \mathrm{W}\right)$ is located in the municipality of Frederico Westphalen, state of Rio Grande do Sul. The dominant vegetation in the area is the Atlantic Forest and the climate is subtropical. The stream is a first order tributary of the Várzea River, in the Uruguay River Basin. The study site is located $470 \mathrm{~m}$ above sea level. Even though agricultural and livestock activities happen in the areas located upstream of the collection sites, the studied area harbors riparian vegetation on both margins of the stream. The streambed is composed of rocks of various sizes, sand, and bedrock.

Monthly collections of $A$. platensis were performed in a $160 \mathrm{~m}$ section of the stream from July 2007 to June 2008. This section was divided into 16 subunits. Aeglids were captured with traps $(\mathrm{N}=16$, one per subunit) placed before the dusk and revised in the morning of the following day. In order to sample the population more thoroughly, a $30 \mathrm{x} 50 \mathrm{~cm}$ hand net with a $60 \mathrm{~cm}$ deep mouth and $1 \mathrm{~mm}$ mesh was also employed. The sampling effort, performed by two people, lasted approximately five minutes per subunit. Environmental variables (water temperature, dissolved oxygen, $\mathrm{pH}$, flow speed, stream depth, stream width and conductivity) were measured monthly in three predetermined locations of the stream (Table I).

Table I. Enviromental parameters recorded for the Lajeado Bonito stream, Uruguay Basin, Rio Grande do Sul state, Brazil.

\begin{tabular}{lrrrr}
\hline \multicolumn{1}{c}{ Parameters } & Spring & Summer & Autumn & Winter \\
\hline Temperature $\left({ }^{\circ} \mathrm{C}\right)$ & 19.830 & 19.830 & 16.270 & 15.200 \\
Dissolved oxygen $(\mathrm{mg} / \mathrm{L})$ & 6.250 & 6.280 & 8.040 & 7.990 \\
Flow speed $(\mathrm{m} / \mathrm{s})$ & 0.420 & 0.340 & 0.620 & 0.240 \\
Conductivity $(\mu \mathrm{S} / \mathrm{cm})$ & 68.680 & 88.510 & 71.990 & 76.960 \\
$\mathrm{pH}$ & 7.520 & 7.660 & 7.760 & 7.320 \\
Stream depth $(\mathrm{cm})$ & 17.780 & 6.480 & 18.670 & 14.890 \\
Stream width $(\mathrm{m})$ & 1.790 & 1.210 & 2.160 & 1.790 \\
Discharge $\left(\mathrm{m}^{3} / \mathrm{s}\right)$ & 0.277 & 0.024 & 0.075 & 0.096 \\
Rainfall $(\mathrm{mm} / \mathrm{month})$ & 246.000 & 97.000 & 198.000 & 147.330 \\
\hline
\end{tabular}

After being separated from other animals captured accidentally, aeglids were identified, sexed, and females were checked for the presence of eggs. Sexing was based on morphological traits, such as the presence of pleopods in adult females, and their absence in adult males. Since younger individuals have inconspicuous pleopods, their sex was determined by observing the genital pores at the base of the third pereiopods (females) or their absence (males) (Bond-Buckup 2003). Biometric measurements were then taken with a digital caliper $(0.01 \mathrm{~mm}$ accuracy), including carapace length (CL - from the tip of the rostrum to the posterior edge of the carapace), carapace width (CW - taken on the height of the upper suture of the gastric region), abdomen width (AW - measured on the second abdominal segment), length of the propodus of the left (LPL) and right (RPL) chelipeds (measured from the posterior proximal margin of the propodus to the tip of the fixed finger) and height of the chelar propodus (HCP - measured perpendicularly to the propodus length). Aeglids were classified according to their CL following Oliveira \& SANTOS (2011): males larger than $19.15 \mathrm{~mm}$ were considered adults, and females larger than $16.5 \mathrm{~mm}$ were determined adults. Aeglids smaller than $8 \mathrm{~mm}$ CL were measured with the help of a stereomicroscope taken to the field site. In order to minimize impact on the studied population, most animals were released back at their capture sites after data recording, with the exception of a few large males from the first collections, which were preserved as vouchers in the scientific collection of the Núcleo de Estudos em Biodiversidade Aquática, Universidade Federal de Santa Maria (voucher number UFSM-C 298). To test for differences in the body measurements of males and females, a Mann-Whitney test was used due to heterocedasticity and non-normality of the data (ZAR 2010). The test was performed in two different configurations: 1 ) using all captured individuals, and 2) using only adult individuals. The exception was the AW in the all-animals sample and the CL and CW in the adults-only, for which normality and homocedasticity could be attained through a $\log 10$ transformation, and for which a Welch two-sample t-test was used.

Sex ratio (male/female) was calculated for each season separately. A chi-square with Yates' correction for small samples was performed to test whether the sex ratio differed from the expected proportion of 1:1 within each season (ZAR 2010). Additionally, data obtained from traps and from handnets were plotted separately to check for possible influences of the sampling method on the sex ratio. The chi-square test performs poorly with small sampling numbers, which can generate spurious results (CRAWLey 2012). Thus, the test was performed with pooled data from captures using traps and hand nets because of the low capture rates in certain seasons. The reproductive and recruitment seasons were estimated qualitatively through the frequency of ovigerous females and unsexed juveniles. Afterwards, we tested if the proportion of captures of ovigerous females and juveniles differed from the expected equal proportion of captures among the seasons using a binomial proportion test (ZAR 2010).

To estimate population density for each season four field samplings (August and November 2007, February and May 
2008) were performed differently. Traps were set on a given day and revisited the morning of the following day, as usual, and then all captured aeglids were marked with a plastic tag placed in their dorsal region. This tag indicated the initial capture site and month of capture. The aeglids were then released back in the stream. The writing on the tags was made with Nanking ink, and the tags were fixed on the aeglid's carapace with cianoacrilate glue. Differently from regular collections, traps were then put back on the stream and the sampling procedure was repeated the following day. The amount of recaptured tagged individuals was recorded. Peterson's estimate (BEGON 1979) was applied to estimate population size: $\mathrm{N}=\mathrm{r}^{*} \mathrm{n} / \mathrm{m}$, where: $(\mathrm{N})$ estimate of the population size, (r) number of animals marked in the first day, (n) number of animals collected in the second day, and (m) number of tagged animals recaptured in the second day.

All data were tested for normality and heterocedasticity with the tests of Shapiro-Wilk and Levene, respectively. All tests were performed in the BioEstat 5.0 software (ZAR 2010, AyrEs et al. 2007), except for the Welch two-sample t-tests, which were performed in the R environment (R CORE TEAm 2013).

\section{RESULTS}

A total of 957 individuals were collected, of which 76 were non-sexed juveniles, 503 males (323 juveniles and 180 adults), 378 females (187 juveniles, 169 adults and 22 ovigerous) (Table II). The CL ranged from 6 to $31.75 \mathrm{~mm}$ for males (median \pm SD: $15.09 \pm 7.35 \mathrm{~mm}$ ), and from 6.08 to 27.92 for females (median \pm SD: $16.11 \pm 5.95 \mathrm{~mm}$ ). There were significant differences only for AW $(t=2.215, \mathrm{p}=0.027)$ between males and females when all aeglids were considered. However, when only adults were considered there was a significant difference between males and females in all dimensions compared $(\mathrm{U}=3.793,9.781,11.150,12.452, \mathrm{p}<0.001$; for AW, LPL, RPL and HCP, respectively; and $\mathrm{t}=-12.226,-11.392$, and $\mathrm{p}<0.001$ for CL and CW, respectively) (Table III). The frequency distribution of size-classes of males and females of $A$. platensis for each season presented a bimodal distribution in all seasons (Figs 1-4).

Table II. Number of individuals of Aegla platensis collected during the four seasons in the Lajeado Bonito stream, Uruguay Basin, Rio Grande do Sul state. (JM) Juvenile males, (AM) adult males, (JF) juvenile females, (AF) adult females, (OF) ovigerous females, (NS) non-sexed juveniles.

\begin{tabular}{lrrrrrrr}
\hline Seasons & JM & AM & JF & AF & OF & NS & Total \\
\hline Spring & 81 & 43 & 33 & 44 & 4 & 50 & 255 \\
Summer & 102 & 22 & 63 & 18 & 7 & 7 & 219 \\
Autumn & 89 & 51 & 61 & 68 & 1 & 13 & 283 \\
Winter & 51 & 64 & 30 & 39 & 10 & 6 & 200 \\
\hline Total & 323 & 180 & 187 & 169 & 22 & 76 & 957 \\
\hline
\end{tabular}

Table III. Medians of the biometric measurements $(\mathrm{mm})$ of the adult individuals of Aegla platensis captured in the Lajeado Bonito stream, Uruguay Basin, Rio Grande do Sul state, Brazil. Different letters in the column indicate statistically significant differences $(p$ $<0.05)$ in the Mann-Whitney $(a, b)$ or t-tests $(c, d)$.

\begin{tabular}{lcccccc}
\hline & $\mathrm{CL}(\mathrm{mm})$ & $\begin{array}{c}\mathrm{CW} \\
(\mathrm{mm})\end{array}$ & $\begin{array}{c}\mathrm{AW} \\
(\mathrm{mm})\end{array}$ & $\begin{array}{c}\mathrm{RPL} \\
(\mathrm{mm})\end{array}$ & $\begin{array}{c}\mathrm{LPL} \\
(\mathrm{mm})\end{array}$ & $\begin{array}{c}\text { ACP } \\
(\mathrm{mm})\end{array}$ \\
\hline Males & $24.87^{\mathrm{c}}$ & $14.67^{\mathrm{c}}$ & $17.67^{\mathrm{a}}$ & $14.12^{\mathrm{a}}$ & $15.91^{\mathrm{a}}$ & $9.55^{\mathrm{a}}$ \\
Females & $21.29^{\mathrm{d}}$ & $12.55^{\mathrm{d}}$ & $16.48^{\mathrm{b}}$ & $10.28^{\mathrm{b}}$ & $10.74^{\mathrm{b}}$ & $6.34^{\mathrm{b}}$ \\
\hline
\end{tabular}
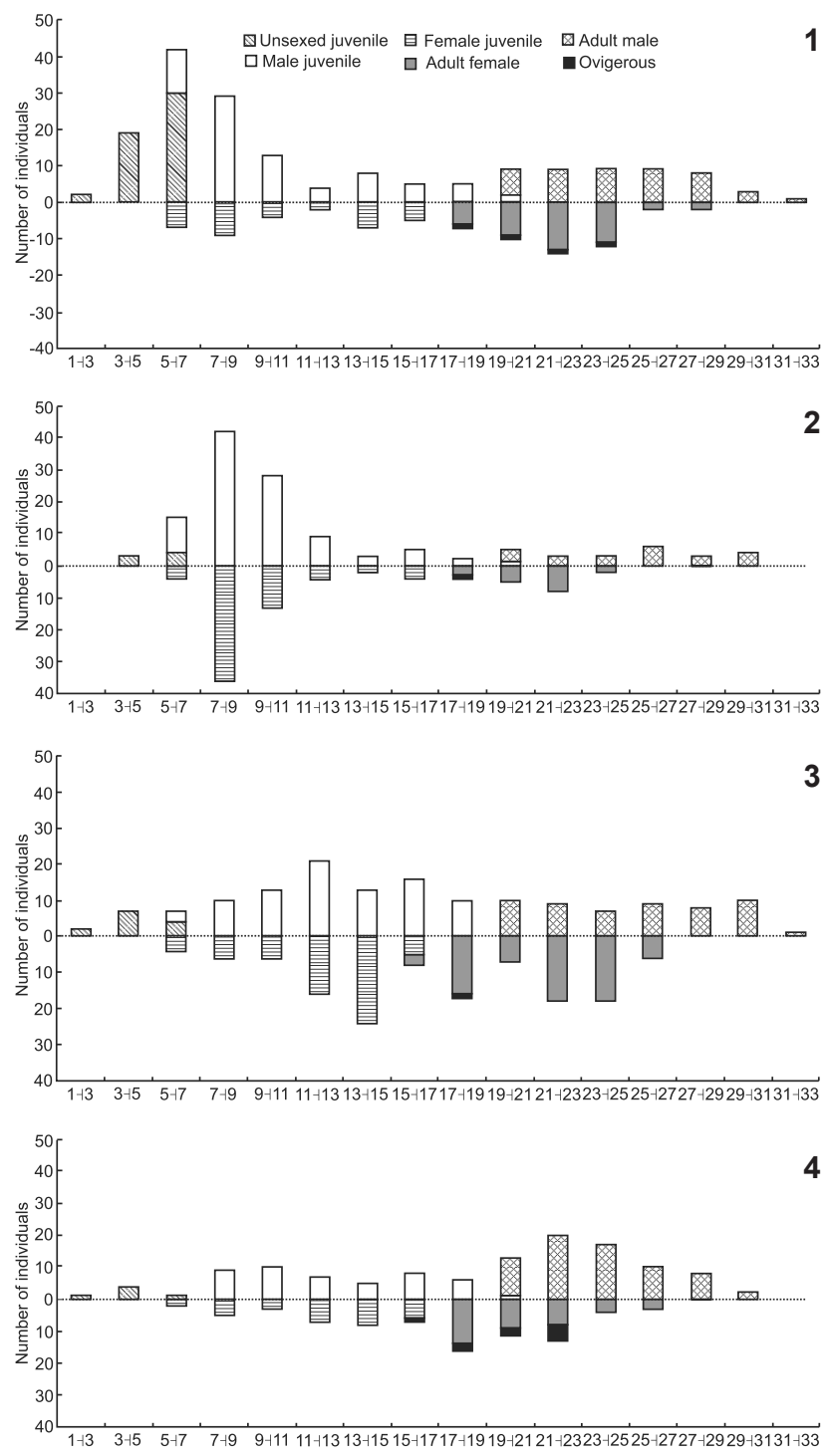

Figures 1-4. Absolute frequencies distribution of cephalothoracic length $(\mathrm{CL})$ classes of individuals of Aegla platensis collected in the Lajeado Bonito stream, Uruguay Basin, Rio Grande do Sul state. Different letters indicate seasons: (1) spring; (2) summer; (3) autumn and (4) winter. 
Males were more common in the spring and winter, with no difference for the other seasons, when all captures were considered (spring: $\chi^{2}=8.605, \mathrm{df}=1, \mathrm{p}=0.003$; summer: $\chi^{2}=$ 2.151, df $=1, \mathrm{p}=0.142$; autumn: $\chi^{2}=0.034, \mathrm{df}=1, \mathrm{p}=0.853$; winter: $\chi^{2}=6.314, \mathrm{df}=1, \mathrm{p}=0.012$ ). The highest proportion of males was $60.48 \%$, in the spring (Fig. 5). The number of ovigerous females caught (22) represented $5.82 \%$ of all the females. These were caught in all seasons, with a higher frequency in winter and summer, and the lowest frequency in the autumn. There was significant difference among the seasons, probably due to the small number of ovigerous females caught in the autumn (only $1 ; \chi^{2}=24.735, \mathrm{df}=3, \mathrm{p}<0.001$; Fig. 6). Juveniles were caught throughout the sampling period, with a higher frequency during the spring $\left(\chi^{2}=63.104, \mathrm{df}=3, \mathrm{p}<0.001\right.$; Fig. 6). Density ranged from 1.80 to 3.83 ind. $\mathrm{m}^{-2}$, with the highest values in the winter (Table IV).

Table IV. Petersen's estimate of population size of Aegla platensis in the Lajeado Bonito stream, Uruguay Basin, Rio Grande do Sul state, Brazil.

\begin{tabular}{lccccc}
\hline Season & $\begin{array}{c}\text { Marked in } \\
\text { the } 1^{\text {st }} \text { day }\end{array}$ & $\begin{array}{c}\text { Captured } \\
2^{\text {nd }} \text { day }\end{array}$ & $\begin{array}{c}\text { Marked and } \\
\text { recaptured }\end{array}$ & $\begin{array}{c}\text { Population } \\
\text { estimate }\end{array}$ & Individuals $/ \mathrm{m}^{2}$ \\
\hline Winter & 25 & 72 & 2 & 900 & 3.83 \\
Spring & 29 & 73 & 5 & 423 & 1.80 \\
Summer & 18 & 86 & 2 & 772 & 3.29 \\
Autumn & 23 & 95 & 4 & 547 & 2.33 \\
\hline
\end{tabular}

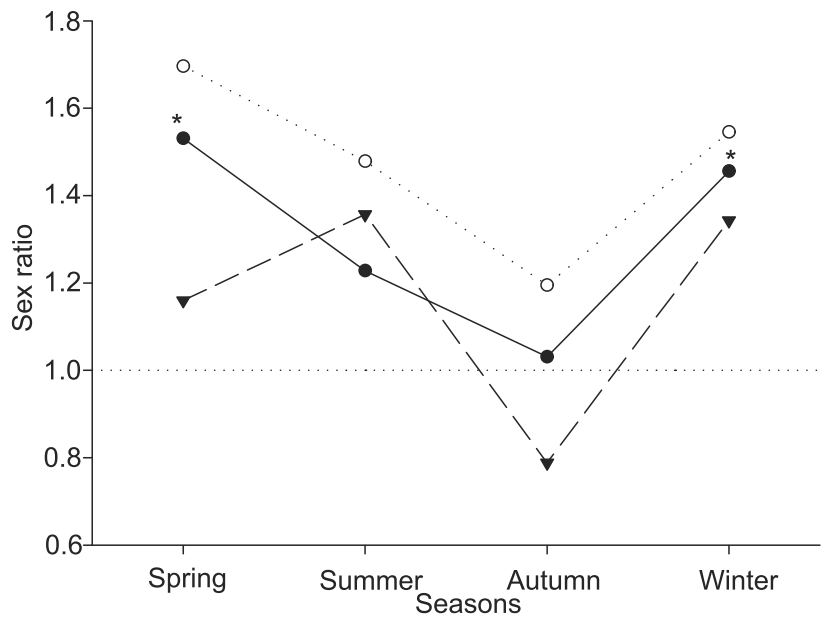

Figure 5. Relative frequency of males and females of Aegla platensis in the four seasons during the sampling period in the Lajeado Bonito stream, Uruguay Basin, Rio Grande do Sul state. Trap captures, handnet captures, and global (traps + handnet captures) are plotted separately. The asterisk $\left({ }^{*}\right)$ denotes statistical difference between the number of males and females by the Chi-square test $(p<0.05)$ for the global dataset. $(\bullet)$ Global, $(O)$ hand net, ( $)$ trap.

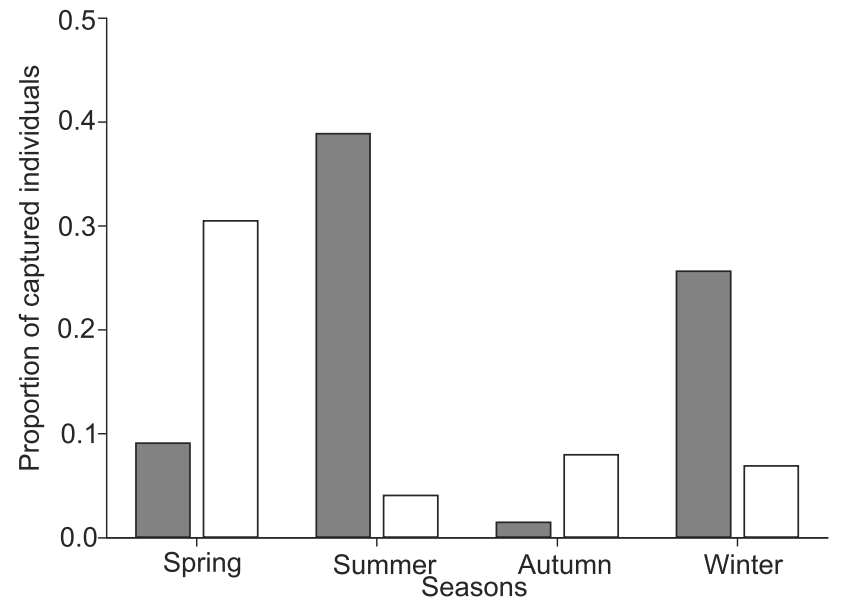

Figure 6. Number of ovigerous females and unsexed juveniles of Aegla platensis in the Lajeado Bonito stream, Uruguay Basin, Rio Grande do Sul state. Individuals were captured during four seasons. Frequencies of capture were distinct from the expected among the four seasons (Chi-square test, $p<0.05$ for ovigerous females and juveniles). ( $\square$ ) Ovigerous, ( $\square$ ) unsexed juveniles.

\section{DISCUSSION}

In the population studied here (Uruguay River Basin, henceforth, UB), adult males had larger body dimensions than their female counterparts (except for AW, which is larger in females, even considering the juveniles). These data agree with the pattern described for most aeglids studied so far, where there is clear sexual dimorphism, with males prevailing in the larger size-classes (Colpo et al. 2005, Trevisan \& Santos 2012, Trevisan et al. 2012), and females possessing broader abdomens for egg-incubation (López-Greco et al. 2004). Interestingly enough, one of the few studies that does not fit this pattern is the other previously studied population of A. platensis in the Guaíba Basin (henceforth, GB), where females were larger than males (Bueno \& Bond-Buckup 2000). Since sexual dimorphism with larger males is a characteristic of the group (BARRíA et al. 2014, BOND-Buckup \& BuCKup 1994), a possible explanation for these opposite results might be the sampling methods adopted (see below for a more detailed discussion).

The maximum size of the animals also differed between UB and GB: maximum CL for males and females were of 17.39 and $19.12 \mathrm{~mm}$ for $\mathrm{GB}$, and of 31.75 and $27.92 \mathrm{~mm}$ for $\mathrm{UB}$, respectively (BuENo \& BOND-BucKup 2000, Table V). Animals from UB were $50 \%$ larger than those registered for the GB. The different sampling and measuring methods adopted could account for this. In GB, the CL measurements did not include the rostrum, while our data include it. However, the rostrum would increase the CL size of the aeglids in approximately $10 \%$, which is certainly not enough to compensate for a size difference of $66 \%$ in relation to animals from the UB. Additionally, BuENo \& 
BOND-Buckup (2000) only employed manual search, while we employed a combination of traps and handnet. The use of traps could affect the mean and maximum size of the animals captured. We found differences in the mean size of individuals captured by traps $(21.83 \pm 4.84 \mathrm{~mm})$ and handnets $(12.76 \pm$ $6.34 \mathrm{~mm}$ ), similar to what has been found for other decapod crustaceans. However, this was not the case for the maximum size, since the largest aeglid caught by traps had $31.75 \mathrm{~mm} \mathrm{CL}$, while the largest caught by hand-net had $30.65 \mathrm{~mm}$ CL. This shows that despite the fact that traps tend to capture larger individuals, handnet is still able to sample large specimens, and is thus considered an appropriate collecting gear to estimate size range. We think that it is safe to conclude that animals from the UB are considerably larger than GB.

Table V. Sampling methods and population parameters of Aegla platensis evaluated for the populations of the Uruguay River (this study) and Guaíba Basins (BUENo \& BOND-BuCKUP 2000), respectively.

\begin{tabular}{lll}
\hline \multicolumn{1}{c}{ Parameters } & Uruguay River Basin & Guaíba Basin \\
\hline Sex ratio (M:F) & $1.33: 1$ & $1.08: 1$ \\
Population density $\left(\mathrm{ind} / \mathrm{m}^{2}\right)$ & $1.8-3.83$ & $8.7-19$ \\
Sexual dimorphism & Present, males larger & $\begin{array}{l}\text { Present, females } \\
\text { larger }\end{array}$ \\
Size of the largest male $(\mathrm{mm})$ & 31.75 & 17.39 \\
Size of the largest female $(\mathrm{mm})$ & 27.92 & 19.12 \\
Population structure & Bimodal & Bimodal \\
Reproductive period & $\begin{array}{l}\text { Year-round, peak in } \\
\text { coldest months }\end{array}$ & $\begin{array}{l}\text { Year-round, peak } \\
\text { in coldest months }\end{array}$ \\
Sampling technique & Handnet + traps & Handnet \\
\hline
\end{tabular}

The sex ratio also differed between GB and UB. In GB, it did not differ significantly from 1:1, while the opposite was found in UB, where it differed from the 1:1 expected proportion in the spring and winter, with an overall sex ratio of 1.33:1. Both results fit the pattern recorded for aeglids, in which the sex ratio ranges from 1:1 to values skewed towards males (Table $\mathrm{VI})$. Once again, the effect of the sampling method makes it difficult to distinguish between actual differences between the species/populations, and the effects of the different sampling methods chosen by each author. The tendency to capture more large adult males using traps had already been demonstrated in crayfish surveys (BEATTY et al. 2004, 2011), and it is relatively safe to infer that the same is true for aeglids (BuEno et al. 2007, Teodósio \& Masunari 2009, Grabowski et al. 2013). In this study, however, when analyzing the sex ratio of aeglids captured by hand-net and by traps (Fig. 5), we can see that the ratio was more skewed towards males in the hand-net captures than in the traps. Thus, we conclude that the difference regarding the sex ratio between GB and UB is not an effect of the methods chosen, but that it reflects an actual difference between these populations.
Table VI. Sex ratio and population density parameters of published studies on Brazilian species of Aegla.

\begin{tabular}{|c|c|c|c|}
\hline Species & $\begin{array}{c}\text { Sex ratio } \\
\text { (M:F) }\end{array}$ & $\begin{array}{l}\text { Density } \\
\left(\text { ind } / \mathrm{m}^{2}\right)\end{array}$ & Authors \\
\hline A. castro & $1: 1$ & - & SWIECH-AYoub \& MaSUnARI (2001) \\
\hline A. castro & $1.08: 1$ & - & Fransozo et al. (2003) \\
\hline A. franca & - & $2.2-2.7$ & BUENo et al. (2007) \\
\hline A. franciscana & $1: 1$ & - & GonçALVES et al. (2006) \\
\hline A. leptodactyla & $1.19: 1$ & - & NoRo \& BuCKUP (2002) \\
\hline A. longirostri & $1: 1$ & - & Colpo et al. (2005) \\
\hline A. parana & $2: 1^{*}$ & - & GrabowsKI et al. (2013) \\
\hline A. paulensis & $1.66: 1^{*}$ & - & COHEN et al. (2011) \\
\hline A. platensis & $1.08: 1$ & 8.7-19 & BUENO \& BOND-BUCKUP (2000) \\
\hline A. platensis & $1.33: 1^{*}$ & $1.8-3.83$ & Current study \\
\hline A. schmitti & $2: 1^{*}$ & - & Teodósıo \& MasunarI (2009) \\
\hline
\end{tabular}

* Sex ratio statistically different from an 1:1 expected proportion.

Ovigerous females were captured year-round, with a peak in the colder months (late winter and early spring). Thus, our data agree with the pattern known for other Brazilian species of Aegla, where the reproduction is either year-round with peaks in the colder months (Bueno \& Bond-BucKup 2000, Colpo et al. 2005), or just concentrated in the colder months (Teodósio \& Masunari 2009, GrabowsKi et al. 2013), including GB. The frequency of juveniles also follows a similar pattern: juveniles were captured year-round, being more abundant in the spring following the peak of the reproductive season (BuENo \& BondBucKup 2000) (Fig. 6). The population structure was bimodal, with two age groups easily distinguishable in the size-class frequency distribution (Figs 1-4). This is in agreement with information for other aeglids, which also show two distinct cohorts in the population (e.g., Bueno \& Bond-Buckup 2000, Fransozo et al. 2003).

The density also differed markedly between localities, being much lower in UB than in GB. In fact, the density of A. platensis in UB was much more similar to the density of another species, A. franca Schmitt, 1942, in the Barro Preto stream (Minas Gerais state, Brazil), than to the density of its conspecific in GB (Table V). Even though the capture methods used by Bueno \& BOND-BuCKup (2000) differ from ours, and may have affected our density results, the difference between both estimates is over $120 \%$. Considering the markedly larger size of the aeglids in UB, one can expect that their populations will exhibit lower densities. This is even more likely if we consider the aggressive nature of aeglids (Ayres-Peres et al. 2011, PALAOro et al. 2013). In crayfish, spatial patterns investigated in natural environments show that dominant animals (i.e., the largest) are more spaced from other crayfish than smaller individuals (Fero \& Moore 2008). Although there are no such studies for aeglids, their ecological (BurRess et al. 2013) and behavioral (Moore 2007, Ayres-Peres et al. 2011) similarities with crayfish, 
along with our results, support the idea of a negative relationship between body size and density in A. platensis.

In general terms, the population structure of UB agrees with the known pattern for aeglids, presenting sexual dimorphism with larger males, a bimodal distribution of the sizeclass frequencies, reproduction concentrated in the coldest months of the year and release of juveniles in the following season (Rосна et al. 2010, Cohen et al. 2011). When compared to $\mathrm{GB}$, however, some differences can be highlighted: aeglids were much larger in UB than GB; the larger aeglids were males in $\mathrm{UB}$ and females in GB; the sex ratio was skewed towards males in UB, and similar to 1:1 in GB; and population density values were at least two times higher in GB than in UB. Differences in these population biology characteristics can also be a result of different environmental pressures. BÜCKER et al. (2008) have shown that the spatial micro distribution of $A$. platensis and A. itacolomiensis Bond-Buckup \& Buckup, 1994 are correlated with the availability of coarse organic matter: the distribution of $A$. platensis was explained by the availability of twigs, followed by fragmented leaves, while the distribution of $A$. itacolomiensis was explained by fragmented leaves, followed by twigs. However, Bueno \& Bond-Buckup (2000) do not present any environmental variable other than temperature. Furthermore, BÜCKER et al. (2008) make a much more detailed surveillance of environmental variables, but do not provide any data regarding the size, density, or other population biology parameters.

The only similarities between UB and GB were the bimodal population structure and the reproduction peak on the colder months (Table V). Nevertheless, these characteristics are shared by most Aegla species studied so far (e.g., Fransozo et al. 2003, Gonçalves et al. 2006, Teodósio \& Masunari 2009), and thus, cannot be considered a species-specific characteristic. Conversely, the maximum size, sexual dimorphism, sex ratio and population density clearly differed between the two populations. Albeit variation in population parameters is expected, and sampling methods can bias the results, the differences between UB and GB are very marked, eventually presenting differences of over $100 \%$ in certain values. If we consider the geographical isolation between the two river basins (SCHWARZBOLD 2010), alongside the evidences for ecological differences, it becomes clear that molecular studies might be the best choice to elucidate if this is a case of ecological differences between populations, or if this a case of cryptic species (Marchiori et al. 2014).

The variety of methods employed by researchers is by far the greatest obstacle to reliable comparisons between population studies on Aegla. More specifically, the choice of the capture method (baited traps, manual search, handnet, Surber sampler, or any combination of these) seems to bias the results. A clear example can be seen in Table VI. The four studies of Aegla where the sex ratio differed significantly from 1:1 were the ones that employed traps, with the three with the more skewed sex ratios being those that relied solely on traps as the sampling method. This issue has already been addressed by previous authors (e.g., BuENo et al. 2007, GRABOwsKi et al. 2013). Despite this, there is still no consensus among researchers on the best methods.

In conclusion, $A$. platensis presented marked differences from one population to another. These differences can be attributed partially to the different sampling methods used by different authors. These differences, along with isolation between the two river basins, suggest that molecular studies are needed to elucidate the taxonomic status of the populations of this species. The only similarities between the populations were common to many Aegla species, which highlights the need of a standardized technique to perform population studies in these anomurans, so that more reliable and less speculative comparisons can be made.

\section{ACKNOWLEDGMENTS}

We would like to thank CAPES for the scholarships for AVP and DO; CAPES/FAPERGS for the scholarship for MMD, and CNPq for the productivity grant for SS (308598/2011-3). We would also like to thank our colleagues at the Núcleo de Estudos em Biodiversidade Aquática for their help in the field work, T.M. Dias, two anonymous reviewers, and A.S. Melo for the helpful comments and suggestions that certainly improved the manuscript.

\section{LITERATURE CITED}

Austin, C.M. 1998. Intra-specific variation in clutch and brood size and rate of development in the yabby, Cherax destructor (Decapoda: Parastacidae). Aquaculture 167: 147-159. doi: 10.1016/S0044-8486(98)00306-8.

Ayres, M.; M. Ayres Jr; D.L. Ayres \& A.S. Santos. 2007. Bioestat 5.0: aplicações estatísticas nas áreas das Ciências Biológicas e Médicas. Belém, Sociedade Civil Mamirauá.

Ayres-Peres, L.; P.B. Araujo \& S. Santos. 2011. Description of the agonistic behavior of Aegla longirostri (Decapoda: Aeglidae). Journal of Crustacean Biology 31 (3): 379-388. doi: 10.1651/10-3422.1.

Barría, E.M.; S. Santos; C.G. Jara \& C.J. Butler. 2014. Sexual dimorphism in the cephalothorax of freshwater crabs of the genus Aegla Leach from Chile (Decapoda, Anomura, Aeglidae): an interspecific approach based on distance variables. Zoomorphology. doi: 10.1007/s00435-014-0231-x.

Beatty S.J.; D.L. Morgan \& H.S. Gill. 2004. Biology of a translocated population of Cherax cainii Austin \& Ryan, 2002 in a western Australian river. Crustaceana 77 (11): 13291351. doi: 10.1163/1568540043166010.

Beatty S.J.: M. de Graaf; B. Molony; V. Nguyen \& K. Pollock. 2011. Plasticity in population biology of Cherax cainii (Decapoda: Parastacidae) inhabiting lentic and lotic environments in south-western Australia: Implications for the sustainable 
management of the recreational ûshery. Fisheries Research 110: 312-324. doi: 10.1016/j.fishres.2011.04.021.

BEGON, M. 1979. Investigating animal abundance: capturerecapture techniques for biologists. London, Edward Arnold.

Bond-Buckup, G. 2003. A Família Aeglidae, p. 21-116. In: G.A.S. Melo (Ed.). Manual de identificação dos Crustacea Decapoda de água doce do Brasil. São Paulo, Editora Loyola.

Bond-Buckup, G. \& L. Buckup. 1994. A Família Aeglidae (Crustacea, Decapoda, Anomura). Arquivos de Zoologia 32 (4): 159-347.

Bond-Buckup, G.; C.G. Jara; M. Pérez-Losada; L. Buckup \& K.A. Crandall. 2008. Global diversity of crabs (Aeglidae: Anomura: Decapoda) in freshwater. Hydrobiologia 595: 267-273. doi: 10.1007/s10750-007-9022-4.

Bücker, F; R. Gonçalves; G. Bond-Buckup \& A.S. Melo. 2008. Effect of the environmental variables on the distribution of two freshwater crabs (Anomura: Aeglidae). Journal of Crustacean Biology 28 (2): 248-251. doi: 10.1651/0278-0372(2008) 028[0248:EOEVOT]2.0.CO;2.

Buckup, L. \& G. Bond-Buckup. 1999. Os crustáceos do Rio Grande do Sul. Porto Alegre, Editora UFRGS.

Bueno, A.A.P. \& G. Bond-BucKuP. 2000. Dinâmica populacional de Aegla platensis Schmitt (Crustacea, Decapoda, Aeglidae). Revista Brasileira de Zoologia 17 (1): 43-49. doi: 10.1590/ S0101-81752000000100005.

Bueno, A.A.P.; G. Bond-Buckup \& L. Buckup. 2000. Crescimento de Aegla platensis Schmitt em ambiente natural (Crustacea, Decapoda, Aeglidae). Revista Brasileira de Zoologia 17 (1): 51-60. doi: 10.1590/S0101-81752000000100006.

Bueno, S.L.S.; R.M. Shimizu \& S.S. DA Rocha. 2007. Estimating the population size of Aegla franca (Decapoda: Anomura: Aeglidae) by mark-recapture technique from an isolated section of Barro Preto stream, county of Claraval, state of Minas Gerais, southeastern Brazil. Journal of Crustacean Biology 27 (4): 553-559. doi: 10.1651/S-2762.1.

Burress, E.D.; M.M. Gangloff \& L. Siefferman. 2013. Trophic analysis of two subtropical South American freshwater crabs using stable isotope ratios. Hydrobiologia 702: 5-13. doi: 10.1007/s10750-012-1290-y.

Byron, C.J. \& K.A. Wilson. 2001. Rusty crayfish (Orconectes rusticus) Movement within and between habitats in Trout Lake, Vilas County, Wisconsin. Journal of the North American Benthological Society 20 (4): 606-614.

Cohen, F.P.A.; B.F. Takano; R.M. Shimizu \& S.L.S. Bueno. 2011. Life cycle and population structure of Aegla paulensis (Decapoda: Anomura: Aeglidae). Journal of Crustacean Biology 31 (3): 389-395. doi: 10.1651/10-3415.1.

Cogo, G.B. \& S. SAntos. 2013. The role of aeglids in shredding organic matter in Neotropical streams. Journal of Crustacean Biology 33 (4): 519-526. doi: 10.1163/ 1937240X-00002165.
Colpo, K.D.; L.R. Oliveira \& S. Santos. 2005. Population biology of the freshwater anomuran Aegla longirostri (Crustacea, Anomura, Aeglidae) from Ibicuí-Mirim River, Itaára, RS, Brazil. Journal of Crustacean Biology 25 (3): 495-499. doi: 10.1651/C-2543.

Crawley, M.J. 2012. The R book. Chichester, John Wiley, $2^{\text {nd }}$ ed.

Dalosto, M. \& S. Santos. 2011. Differences in oxygen consumption and diel activity as adaptations related to microhabitat in Neotropical freshwater decapods (Crustacea). Comparative Biochemistry and Physiology, Part A 160: 461-466. doi: 10.1016/j.cbpa.2011.07.026.

Fero, K. \& P.A. Moore. 2008. Social spacing of crayfish in natural habitats: what role does dominance plays? Behavioral Ecology Sociobiology 62: 1119-1125. doi: 10.1007/s00265007-0540-x.

Fransozo, A.; R.C. Costa; A.L.D. Reigada \& J.M. Nakagaki. 2003. Population structure of Aegla castro Schmitt, 1942 (Crustacea: Anomura: Aeglidae) from Itatinga (SP), Brazil. Acta Limnologica Brasiliensia 15 (2): 13-20.

Gonçalves, R.S.; D.S. Castiglioni \& G. Bond-Buckup. 2006. Ecologia populacional de Aegla franciscana (Crustacea, Decapoda, Anomura) em São Francisco de Paula, RS, Brasil. Iheringia, Série Zoologia, 96 (1): 109-114. doi: 10.1590/S007347212006000100019.

Grabowski, R.C.; S. Santos \& A.L. Castilho. 2013. Reproductive ecology and size of sexual maturity in the anomuran crab Aegla parana (Decapoda: Aeglidae). Journal of Crustacean Biology 33 (3): 332-338. doi: 10.1163/1937240X-00002148.

Honan, J.A. \& B.D. Mitchell. 1995. Reproduction of Euastacus bispinosus Clark (Decapoda: Parastacidae), and trends in the reproductive characteristics of freshwater crayûsh. Marine and Freshwater Research 46: 485-499. doi: 10.1071/ MF9950485.

López-Greco, L.; V. Viau; M. Lavolpe; G. Bond-Buckup \& E.M. Rodriguez. 2004. Juvenile hatching and maternal care in Aegla uruguayana (Anomura, Aeglidae). Journal of Crustacean Biology 24 (2): 309-313. doi: 10.1651/C-2441.

Marchiori, A.B.; M.L. Bartholomei-Santos \& S. Santos. 2014. Intraspecific variation in Aegla longirostri (Crustacea: Decapoda: Anomura) revealed by geometric morphometrics: evidence of an ongoing speciation process. Biological Journal of the Linnean Society 112 (1): 31-39. doi: 10.1111/ bij.12256.

Moore, P.A. 2007. Agonistic behavior in freshwater crayûsh: the inûuence of intrinsic and extrinsic factors on aggressive encounters and dominance, p. 90-114. In: J.E. Duffy \& M. Thiel (Eds). Evolutionary ecology of social and sexual systems - crustaceans as model organisms. Oxford, Oxford University Press.

Noro, C.K. \& L. Buckup. 2002. Biologia reprodutiva e ecologia de Aegla leptodactyla Buckup \& Rossi (Crustacea, Anomura, Aeglidae). Revista Brasileira de Zoologia 19 (4): 1063-1074. doi: 10.1590/S0101-81752002000400011. 
Nyström, P. 2002. Ecology, p. 192-235. In: D.M. Holdich (Ed.). Biology of Freshwater Crayfish. Oxford, Blackwell Science.

Oliveira, D. \& S. Santos. 2011. Maturidade sexual morfológica de Aegla platensis (Crustacea, Decapoda, Anomura) no Lajeado Bonito, norte do estado do Rio Grande do Sul, Brasil. Iheringia, Série Zoologia, 101 (1-2): 127-130. doi: 10.1590/ S0073-47212011000100018.

Palaoro, A.V.; L. Ayres-Peres \& S. Santos. 2013. Modulation of male aggressiveness through different communication pathways. Behavioral Ecology and Sociobiology 67 (2): 283-292. doi: 10.1007/s00265-012-1448-7.

Pérez-Losada, M.; G. Bond-Buckup; C.G. Jara \& K.A. Crandall. 2009. Conservation assessment of southern South American freshwater ecoregions on the basis of the distribution and genetic diversity of crabs from the genus Aegla. Conservation Biology 23 (3): 692-702. doi: 10.1111/j.1523-1739.2008.01161.x.

R CORE TEAM. 2013. R: A language and environment for statistical computing. Vienna, R Foundation for Statistical Computing.

Roсha, S.S.; R.M. Shimizu \& S.L.S. Bueno. 2010. Reproductive biology in females of Aegla strinatii (Decapoda: Anomura: Aeglidae). Journal of Crustacean Biology 30 (4): 589-596. doi: 10.1651/10-3285.1.

Santos, S.; C.G.Jara; M.L. Bartholomei-Santos; M. Pérez-Losada $\&$ K.A. Crandall. 2013. New species and records of the genus Aegla Leach, 1820 (Crustacea, Anomura, Aeglidae) from the West-Central region of Rio Grande do Sul, Brazil. Nauplius 21 (2): 211-223.

Submitted: 29.IX.2013; Accepted: 06.IV.2014.

Editorial responsibility: Adriano S. Melo
Schwarzbold, A. 2010. Ciência \& Ambiente n. 41 - Os Rios da América. Santa Maria, Editora Universidade Federal de Santa Maria.

Siqueira, A.F.; A.V. Palaoro \& S. Santos. 2013. Mate preference in the neotropical freshwater crab Aegla longirostri (Decapoda: Anomura): does the size matter? Marine and Freshwater Behaviour and Physiology 46 (4): 219-227. doi: 10.1080/ 10236244.2013.808832.

Swiech-Ayoub, B.P. \& S. Masunari. 2001. Flutuações temporal e espacial de abundância e composição de tamanho de Aegla castro Schmitt (Crustacea, Anomura, Aeglidae) no Buraco do Padre, Ponta Grossa, Paraná, Brasil. Revista Brasileira de Zoologia 18 (3): 1003-1017. doi: 10.1590/S010181752001000300032.

Teodósio, E.A.O. \& S. Masunari. 2009. Estrutura populacional de Aegla schmitti (Crustacea: Anomura: Aeglidae) nos reservatórios dos Mananciais da Serra, Piraquara, Paraná, Brasil. Zoologia 26 (1): 19-24. doi: 10.1590/S1984-46702009000100004.

Trevisan, A. \& S. Santos. 2012. Morphological sexual maturity, sexual dimorphism and heterochely in Aegla manuinflata (Anomura). Journal of Crustacean Biology 32 (4): 519527. doi:10.1163/193724012X635944.

Trevisan, A.; M.Z. Marochi; M. Costa; S. Santos \& S. Masunari. 2012. Sexual dimorphism in Aegla marginata (Decapoda: Anomura). Nauplius 20: 75-86.

ZAR, J. 2010. Biostatistical analysis. New Jersey, $5^{\text {th }}$ ed., Prentice Hall. 